\title{
NON-FINANCIAL REPORTING STANDARDS AND EVALUATION OF THEIR USE ILLUSTRATED WITH EXAMPLE OF POLISH LISTED COMPANIES
}

\author{
MAGDALENA WÓJCIK-JURKIEWICZ, ${ }^{1}$ BEATA SADOWSKA ${ }^{2}$
}

${ }^{1}$ Cracow University of Economics, Faculty of Management, POLAND

e-mail: magdalena.wojcik-jurkiewicz@uek.krakow.pl

${ }^{2}$ University of Szczecin, Faculty of Management and Economics of Services, POLAND

e-mail: beata.sadowska@wzieu.pl

RECEIVED
ACCEPTED
JEL
CLASSIFICATION

KEYWORDS

ABSTRACT
18 January 2018

2 September 2018

M14, M48

non-financial reporting, CSR, Directive 2014/95/EU, Public Interest Entities (PIEs), standards, management

The introduction of the obligation to publish non-financial data has been awaited by stakeholders for a long time. This obligation has been in effect since the beginning of 2017 for selected companies listed on the stock exchange, i.e. Public Interest Entities (PIEs). The paper attempts to assess the current state of non-financial reporting based on the standards used by PIEs in the first year of its validity. The authors attempted to assess the new reporting obligation and put forward the following main hypothesis: Polish listed companies, and in particular, public interest entities are not prepared to implement the provisions of the Accounting Act, which is the transposition of Directive 2014/95/EU. The research provided evidence that the highest percentage of companies reported on the basis of GRI standards and other combinations of GRI, GRI G4, SIN, and more than half of the companies proposed their own principles or did not specify them. The research showed the multidimensionality of actions taken by companies in the context of non-financial reporting.

\section{Introduction}

Since 2017, the obligation for listed companies to publish non-financial information in the form of reports or statements has been in effect. This obligation stems from the implementation into the Polish law of Directive 2014/95/EU, which requires certain large public interest entities (PIEs) and capital groups to disclose the extended 
scope of non-financial information. Changes in non-financial reporting are the result of evolutionary changes, thus responding to changing needs and expectations of stakeholders.

\section{Literature review}

The non-financial reporting means corporate social responsibility. Therefore, it is said that the development of the CSR issue and expansion of literature on the subject around the world took place between the 80s and 90s of the last century. The object of these studies is mainly to present the idea of corporate social responsibility and guidelines for reporting on it e.g. Ernst, Ernst (1976), M. Dierkes, L.E. Preston (1977), S.C. Burchell, C. Clubb, A.G. Hopwood (1985), K.E. Nees, A.M. Mirza (1991), R.H. Gray, J. Bebbington, D. Walters (1993), R.H. Gray, R. Kouhy, S. Lavers (1995), L. Moir (2001), W. Garriga, D. Mele (2004), A. Ms Williams, D.S. Siegel, P.M. Wright (2006), A. Okoye (2009), W. Visser (2010), H. Aguinis, A. Galvas (2012) and empirical research in the field of applied practices and factors influencing the scope and quality of information presented. Among the many authors and studies in this research, it is worth pointing out, among others, to: H.J. Hejase, F. Hashem, Ali Al. Dirani, Z. Haddad, K. Atwi (2017), B. Fernandez-Feijoo, S. Romero, S. Ruiz (2014), R. Hahn, M. Kuehnen (2013), J.E. Morhardt (2010), C.A. Adams (2002), C.A. Adams, W.Y. Hill, C.B. Roberts (1995, 1998), A. Belkaoui, R.G. Karpik (1989), L.E. Preston, F. Rey, M. Dierkes (1978). Studies from the literature of Polish authors, which are worth pointing out, are: M. Rozkwitalska (2006), A. Paliwoda-Matiolańska (2009), M. Marcinkowska (2010), W. Gasparski, A. LewickaStrzałecka, B. Rok, G. Szulczewski (2011), A. Herbuś, B. Ślusarczyk (2012), M. Stefańska (2013), B. Bek-Gaik, B. Rymkiewicz (2014), M. Macuda, Ł. Matuszak, E. Różańska (2015), R. Ignatowski, M. Wójcik-Jurkiewicz (2016), D. Jędrzejka (2016), M. Wójcik-Jurkiewicz (2017), E. Gheribi (2017), O. Nosova (2017), M. Wójcik-Jurkiewicz (2018), Ł. Matuszak, E. Różańska (2017), E. Śnieżek, J. Krasodomska, A. Szadziewska (2018).

\section{Method}

To verify the paper's hypothesis, annual reports, CSR reports, sustainable development reports, management reports, and other information published by enterprises on their websites were analysed. The study aims at assessing the state of non-financial reporting among Polish listed companies. For this purpose, the method of analysis and deduction was used in the paper. The critical analysis of references and sources was performed, including analyses of national and foreign scientific publications, the EU directive, the Accounting Act, non-legislative documents, and guidelines of auditors and organisations responsible for non-financial reporting initiatives.

\section{Results}

The awareness and significance of corporate social responsibility and the concept of sustainable development are constantly growing, and as a consequence, the awareness of the need to report information on the entity's activities in non-financial areas referred to as non-financial reporting. Relevant regulations and recommendations refer to these elements of reports, which are to provide context and supplement to the financial statements. Many regulations, recommendations, and good practices have been developed that support the reporting process in this area, illustrated by an example of the GRI Initiative (Global Reporting Initiative). A list of standards used for nonfinancial reporting: GRI Standards/GRI G4, Communication on Progress (COP), International Integrated Reporting 
Framework, KPI for ESG, Carbon Disclosure Project (CDP), PN-ISO 26000:2012 on social responsibility, EMAS (Eco-Management and Audit Scheme) and Non-Financial Information Standard (SIN).

Table 1 presents a list of the non-financial reporting standards, which include standards, code's, guidelines, indicator's (according to their development date criterion) or recommendations concerning this area, specifically the main areas of such activities, most commonly used in business practice.

Table 1. Historical View of Non-Financial Reporting Guidelines

\begin{tabular}{|c|c|c|c|c|}
\hline Year of development & Standard name & Category & Scope & Standard author \\
\hline 1976 & OECD & Code & International & $\begin{array}{l}\text { Organisation for Economic Co- } \\
\text { operation and Development }\end{array}$ \\
\hline 1977 & $\begin{array}{l}\text { Tripartite declaration of the } \\
\text { ILO }\end{array}$ & Code & International & Administrative Council of the ILO \\
\hline 1993/1995 & EMAS & $\begin{array}{l}\text { Environmental } \\
\text { management standards }\end{array}$ & Regional-European & EU Parliament and Council \\
\hline \multirow[t]{2}{*}{2000} & UN Global Compact & Code & International & $\begin{array}{l}\text { Initiative of Secretary General, } \\
\text { Kofi Annan }\end{array}$ \\
\hline & GRI & Reporting indicator & International & Global Reporting Initiative \\
\hline 2010 & ISO 26000 & Standard & International & $\begin{array}{l}\text { International ISO Standardization } \\
\text { Committee }\end{array}$ \\
\hline 2011 & $\begin{array}{l}\text { UN "Protect, Respect and } \\
\text { Remedy" }\end{array}$ & Guidelines & International & UN Human Rights Council \\
\hline 2015 & GRI Standards/GRI G4 & Reporting indicator & International & Global Reporting Initiative \\
\hline 2017 & $\begin{array}{l}\text { SIN (Non-Financial } \\
\text { Information Standard) }\end{array}$ & Environmental standard & Regional-European & $\begin{array}{l}\text { Foundation of Reporting } \\
\text { Standards }\end{array}$ \\
\hline
\end{tabular}

Source: own study based on: Paszkiewicz, Szadziewska (2011), Samelak (2013); Gasparski, Lewicka-Strzałecka, Rok, Szulczewski (2002), Szadziewska, Spigarska, Majerowska (2018), Mikulska, Michalczuk (2014) Ignatowski, Wójcik-Jurkiewicz (2016), Wójcik-Jurkiewicz (2017), Wójcik-Jurkiewicz (2018), SIN (2017), Matuszak, Różańka (2017).

As far as non-financial reporting is concerned, data presentation method is discretionary. However, to encourage businesses to apply unified non-financial reporting principles, the Global Reporting Initiative (GRI) has created publicly available guidelines (principles, indicators) that businesses can use to measure their economic, social, and environmental performance (Zapłata, Kaźmierczak, 2011, p. 174). Such a framework is intended to ensure comparability and transparency of data.

In accordance with the applicable legal regulations, reporting standards can be selected from among the above mentioned international and EU standards characterised by the different scope of information. According to par. 9 of the Directive, entities covered by these regulations may rely on national frameworks, EU frameworks, such as the Eco-Management and Audit Scheme (EMAS), or international frameworks, such as the UN Global Compact, UN Guiding Principles on Business and Human Rights implementing the UN "Protection, Respect and Remedy" Framework, OECD Guidelines for Multinational Enterprises, the ISO 26000 standard, the ILO Tripartite Declaration of Principles concerning Multinational Enterprises and Social Policy, GRI (Global Reporting Initiative), or other recognised international frameworks. Table 2 presents the areas and principles of non-financial reporting according to the standards indicated in Table 1. 
Table 2. Guidelines for Non-Financial Reporting in Accordance with the Applicable Rules

\begin{tabular}{|c|c|c|}
\hline Standard Name & Reporting Areas & Reporting Principles \\
\hline ISO 26000 & $\begin{array}{l}\text { Organisational governance } \\
\text { Human resources management } \\
\text { Good business conduct } \\
\text { Consumer issues } \\
\text { Human rights } \\
\text { Natural environment } \\
\text { Community involvement and development }\end{array}$ & $\begin{array}{l}\text { - Presentation of an honest and complete picture of CSR. } \\
\text { - Presentation according to the CSR key areas. } \\
\text { - Presentation of information: understandable, accurate, } \\
\text { objective, and complete }\end{array}$ \\
\hline UNGC & $\begin{array}{l}\text { Human rights } \\
\text { Environmental protection } \\
\text { Labour standards } \\
\text { Anti-corruption }\end{array}$ & $\begin{array}{l}\text { The clear structure of the report informing about costs and } \\
\text { progress in the implementation of the ten principles }\end{array}$ \\
\hline EMAS & Environmental management & Clear and complete structure of the report \\
\hline OECD & $\begin{array}{l}\text { Human rights } \\
\text { Sustainable development } \\
\text { Employment and employment relationships } \\
\text { Environmental protection } \\
\text { Anti-corruption } \\
\text { Protection of consumers' interests }\end{array}$ & Transparency of information \\
\hline GRI & $\begin{array}{l}\text { In accordance with the principle of materiality, those which } \\
\text { have a significant economic, environmental, and social } \\
\text { impact and significantly influence the assessment of the } \\
\text { enterprise by stakeholders or their decisions }\end{array}$ & $\begin{array}{l}\text { The inclusion of stakeholders - they must be defined, and the } \\
\text { manner of the fulfilment of their interests and expectations must } \\
\text { be explained. } \\
\text { - Sustainable development context } \\
\text { - Materiality } \\
\text { - Completeness }\end{array}$ \\
\hline SIN & $\begin{array}{l}\text { Management area }-15 \text { indicators } \\
\text { Environmental area }-30 \text { indicators } \\
\text { Social and employment area }-78 \text { indicators, three } \\
\text { introductory chapters, and five annexes }\end{array}$ & $\begin{array}{l}\text { - Simple layout and structure } \\
\text { - Support in determining the materiality of non-financial } \\
\text { disclosures } \\
\text { - Adaptation to the specific character of Polish listed companies }\end{array}$ \\
\hline
\end{tabular}

Source: own study based on Bartkowiak (2011), Lament (2017), Kędzior, Kędzior, Wójcik-Jurkiewicz (2017), Maćkowiak, Svobodová (2017). Wójcik-Jurkiewicz (2018).

Social responsibility is considered to be one of the greatest challenges of the 21 st century and plays an increasingly important role in the functioning of many organisations. It is being discussed at length by researchers, both its theoretical (Friedman, 1970; Epstein, Roy, 2001) and empirical (Dahlsrud, 2008; Heslin, Ochoa, 2008) aspects. Corporate Social Responsibility may be understood as making and meeting economic, legal, ethical and discretionary commitments, imposed on a given organization by the parties engaged in its activity (Maignan, Ferrell, Hunt, 1999), or as considering the society's current expectations by the organization in its activity (Commission of the European Communities 2001).

Bearing in mind the non-financial reporting obligation introduced by the Accounting Act, the authors carried out preliminary research, evaluating 167 listed companies (PIEs). Figure 1 presents the results, which confirm the paper's research hypothesis. 


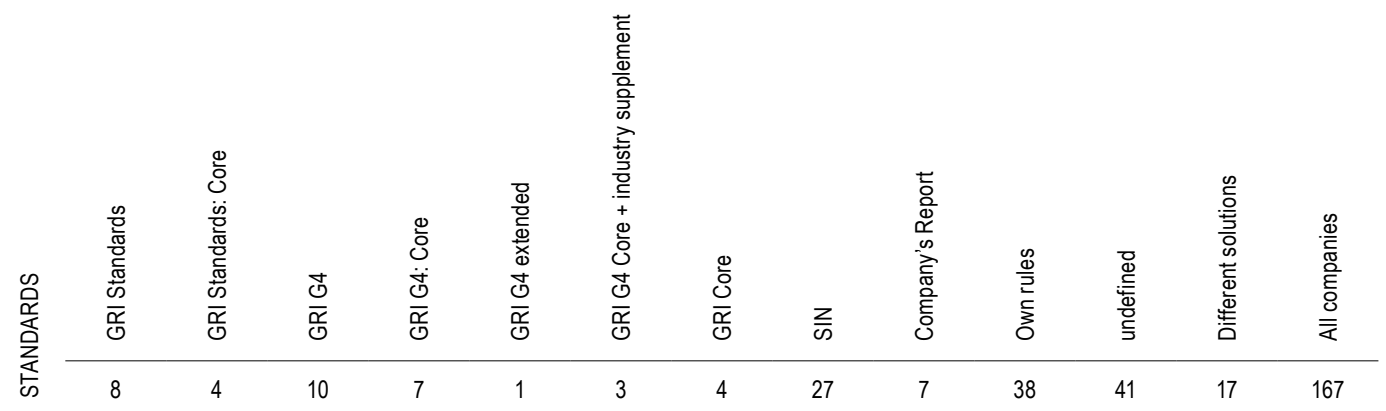

Figure 1. Readiness of Listed Companies for Non-Financial Reporting

Source: own research based on the Polish Public Interest Entities (PIE's) (as of 31 August 2018).

Figure 1 proves the author's thesis that listed companies were not ready for non-financial reporting. It should be noted that less than $38 \%$ of the surveyed companies used the existing standards and guidelines, of which $50 \%$ applied the newly developed SIN. The situation is satisfactory for the SIN standard, while other results still prove the lack of readiness of listed companies to report non-financial information, which may serve as a basis for further explorations and research.

In conclusion, the considerations presented in the paper show that the issue of non-financial reporting requires ordering. Research has shown the need for uniform solutions related to non-financial information reporting, with special consideration of the non-financial reporting concept, as it is increasingly recommended and recognised as s good practice in an enterprise (Śnieżek, Piłacik, 2016). On the other hand, the Legislator emphasises that it is not necessary to more precisely specify the shape and direction of development of non-financial reporting in Poland or other EU countries.

\section{Results supply}

Since there are no clear procedures related to the implementation of non-financial reporting standards, greater transparency of companies and the comparability of the information presented by them may not be possible.

\section{Results demand}

The survey required companies to be ready to prepare a non-financial report, which, obviously required more time and professionalism from the companies. The results expected by the paper's authors were to indicate 2,3 , or even a few solutions, to meet the requirement for transparency and comparability of non-financial data.

\section{Limitations}

A significant limitation of the survey was a small sample which resulted from the fact that some companies did not meet the obligation to draw up a non-financial report. Also, the companies decided to select too many standards as appropriate and single. 


\section{Conclusions}

The analysis of references and the scope of authors' research and other research presented in the paper allowed to verify the research hypothesis, i.e. Polish listed companies, and in particular, public interest entities are not prepared to implement the provisions of the Accounting Act, which is the transposition of Directive 2014/95/EU. It should be noted that a non-financial report is related to the strategy of operation and the organisation management system while fulfilling the legislative obligations.

The authors are fully aware of the limitations of the research, for instance, because of its initial nature and the small sample of only 167 listed companies (PIEs) surveyed in the first year of the new regulations.

The presented facts allow us to conclude that both in qualitative and quantitative terms, non-financial reporting is at the development stage in Poland. The next big challenge for the authors will be to attempt to build an index determining the level of non-financial reporting in Poland.

\section{References}

Bartkowiak, G. (2011). Społeczna odpowiedzialność biznesu w aspekcie teoretycznym i empirycznym. Warszawa: Difin.

Bek-Gaik, B., Rymkiewicz, B. (2014). Społeczna odpowiedzialność przedsiębiorstw a finansowe miary dokonań. Zeszyty Naukowe Uniwersytetu Szczecińskiego, 804. Finanse, Rynki Finansowe, Ubezpieczenia, 67, 137-151.

Directive 2014/95/EU of the European Parliament and of the Council of 22 October 2014 Amending Directive 2013/34/EU as Regards Disclosure of Non-Financial and Diversity Information by Certain Large Undertakings and Groups; EU law: Brussels, Belgium.

Commission of the European Communities (2001). Green Paper, Promoting Framework for Corporate Social Responsibility. Brussels.

Dahlsrud, A. (2008). How corporate social responsibility is defined: An analysis of 37 definitions. Corporate Social Responsibility and Environmental Management, 15, 1-13.

Epstein, M.J., Roy, M.J. (2001). Sustainability in action: Identifying and measuring the key performance drivers. Long Range Planning, 34 (5), 585-604.

Fernandez-Feijoo, B., Romero, S., Ruiz, S. (2014). Effect of stakeholders' pressure on transparency of sustainability reports within the GRI framework. Journal of Business Ethics, 122 (1), 53-63.

Friedman, M. (1970). The social responsibility of business is to increase its profits. The New York Times Magazine, 13/09/1970, 32-33, 122-126.

Gasparski, W., Lewicka-Strzałecka, A., Rok, B., Szulczewski, G. (2011). Odpowiedzialność społeczna i etyka biznesu w polskim życiu gospodarczym. In: W. Kieżun (ed.), Krytycznie i twórczo o zarządzaniu (pp. 391-422). Warszawa: Wolters Kluwer Polska.

Gheribi, E. (2017). Corporate social responsibility in foodservice business in Poland on selected example. European Journal of Service Management, 3 (23), 13-20.

Gray, R.H., Kouhy, R., Lavers, S. (1995). Corporate social and environmental reporting: a review of the literature and a longitudinal study of UK disclosure. Accounting, Auditing and Accountability Journal, 2, 47-77.

GRI Database (2018). GRI Sustainability Disclosure Database 2018. Retrieved from: http://database. globalreporting.org.

Hahn, R., Kuehnen, M. (2013). Determinants of sustainability reporting: a review of results, trends. Theory, and opportunities in an expanding field of research. Journal of Cleaner Production, 59, 5-21.

Herbuś, A., Ślusarczyk, B. (2012). The use of corporate social responsibility idea in business management. Polish Journal of Management Studies, 6, 234-240.

Heslin, P.A., Ochoa, J.D. (2008). Understanding and developing strategic corporate responsibility. Organizational Dynamics, 37 (2), 125-144.

Ignatowski, R., Wójcik-Jurkiewicz, M. (2016). Raportowanie spółek w zakresie społecznie odpowiedzialnego biznesu. In: Z. Dobrowolski, G. Ignatowski, Ł. Sułkowski (eds.), Instrumenty polityki społecznej (pp. 124-142). Warszawa: Difin.

Kędzior, M., Kędzior, D., Wójcik-Jurkiewicz, M. (2017). Wyniki finansowe, ryzyko i koszt kapitału a społeczna odpowiedzialność przedsiębiorstw - przegląd wyników. In: J. Krasodomska (ed.), Społeczna odpowiedzialność biznesu w rachunkowości. Teoria i praktyka (pp. 161-172). Warszawa: Difin. 
Lament, M. (2017). Raportowanie informacji niefinansowych w zakładach ubezpieczeń w Polsce. Zeszyty Teoretyczne Rachunkowości, 91 (147), 63-86.

Macuda, M., Matuszak, Ł., Różańska, E. (2015). The concept of CSR in accounting theory and practice in Poland: an empirical study. Zeszyty Teoretyczne Rachunkowości, 84 (140), 23-45.

Maćkowiak, M., Svobodová, L. (2017). Creating a socially responsible agritourism offer. A market requirement or a manifestation of service providers' system of values? European Journal of Service Management, 4 (24), 39-44.

Maignan, I., Ferrell, O.C., Hult, G.T.M. (1999). Corporate Citizenship: Cultural Antecedents and Business Benefits. Journal of the Academy of Marketing Science, 27, 455-469.

Matuszak, Ł., Różańska, E. (2017). CSR Disclosure in Polish-Listed Companies in the Light of Directive 2014/95/EU Requirements: Empirical Evidence. Sustainability, 9 (12), 1-18.

Marcinkowska, M. (2010). Społeczna odpowiedzialność przedsiębiorstw a ich wyniki ekonomiczne : aspekty teoretyczne. Przegląd Organizacji, 10, 7-10

Morhardt, J.E. (2010). Corporate social responsibility a sustainability reporting on the internet. Business Strategy and the Environment, $19(7), 436-452$

Mikulska, T., Michalczuk, G. (2014). Raportowanie społecznej odpowiedzialności przedsiębiorstwa. Zeszyty Naukowe Uniwersytetu Szczecińskiego, 827, Finanse, Rynki Finansowe, Ubezpieczenia, 69, 209-219.

Nosova, O. (2017). Corporate Social Responsibility in service sector in Ukraine. European Journal of Service Management, 22 (2), 53-60.

Paliwoda-Matiolańska, A. (2009). Odpowiedzialność społeczna w procesie zarządzania przedsiębiorstwem. Warszawa: C.H. Beck.

Paszkiewicz, A., Szadziewska, A. (2011). Raportowanie ekologicznych aspektów działalności w przedsiębiorstwach energetycznych i chemicznych. Zeszyty Naukowe Uniwersytetu Szczecińskiego, 625. Finanse, Rynki Finansowe, Ubezpieczenia, 32, $295-311$.

Samelak, J. (2013). Zintegrowane sprawozdanie przedsiębiorstwa społecznie odpowiedzialnego. Poznań Wydawnictwo Uniwersytetu Ekonomicznego w Poznaniu,.

Standard Informacji Niefinansowych 2017. Interpretacje prawne dyrektywy 2014/95/UE, Fundacja Standardów Raportowania, Warszawa, Retrieved from: https://standardy.org.pl/wppsndrd/wpcontent/uploads/2017/11/SIN_ANEKS_1.pdf.

Szadziewska, A., Spigarska, E., Majerowska, E. (2018). The disclosure of non-financial information by stock-exchange-listed companies in Poland, in the light of the changes introduced by the Directive 2014/95/EU. Zeszyty Teoretyczne Rachunkowości, 99 (155), 65-95.

Śnieżek, E., Krasodomska, J., Szadziewska, A. (2018). Informacje niefinansowe w sprawozdawczości biznesowej przedsiębiorstw. Warszawa: Wydawnictwo Nieoczywiste.

Śnieżek, E., Piłacik, J. (2016). Raportowanie informacji pozafinansowych o społecznej odpowiedzialności w Lasach Państwowych w świetle niektórych koncepcji teoretycznych. Studia Ekonomiczne. Zeszyty Naukowe Uniwersytetu Ekonomicznego w Katowicach, 284, 140-148.

Wójcik-Jurkiewicz, M. (2016). Idea społecznie odpowiedzialnego biznesu a kształtowanie wyniku finansowego spółki. Studia Ekonomiczne. Zeszyty Naukowe Uniwersytetu Ekonomicznego w Katowicach, 253, 140-150.

Wójcik-Jurkiewicz, M. (2018). The Consequences Transposition of the NFI Directive into Polish Law. „International Multidisciplinary Scientific GeoConference SGEM". Surveying Geology \& Mining Ecology Management (SGEM), 18, 571-578. DOI:10.5593/ sgem2018/5.4.

Wójcik-Jurkiewicz, M. (2017). Role of CSR Reporting. Evidence from Poland. Zeszyty Teoretyczne Rachunkowości, 94 (150), $173-188$.

Zapłata, S., Kaźmierczak, M. (2011). Ryzyko, ciągłość biznesu, odpowiedzialność społeczna. Warszawa: Wolters Kluwer.

Cite this anticle aS: Wójcik-Jurkiewicz, M., Sadowska, B. (2018). Non-financial reporting standards and evaluation of their use illustrated with example of Polish listed companies. European Journal of Service Management, 3 (27/2), 539-545. DOI: 10.18276/ejsm.2018. 27/2-66. 